\title{
USO DEL AGUA, MANEJO DE EFLUENTES Y RESIDUOS EN TAMBOS DEL NORESTE DE LA PROVINCIA DE SANTA FE (ARGENTINA) ${ }^{a}$
}

\author{
Badino, O. ${ }^{1 ;}$ Schmidt, E. ${ }^{2}$; Ramos, e. ${ }^{2}$; HerRero, M.A. ${ }^{3 ;}$ \\ Weidmann, R. ${ }^{1} \&$ Giraudo, F. ${ }^{2}$
}

\begin{abstract}
RESUMEN
El noreste de la provincia de Santa Fe, es un área extra cuenca, potencial para la expansión de la lechería. Se relevaron las prácticas relacionadas al uso del agua, manejo de efluentes y residuos en tambos de los departamentos Vera, General Obligado, Norte de San Justo y San Javier. En el $27 \%$ de los establecimientos se realiza de manejo de efluentes. El 56\% de los tambos deriva sus efluentes a lagunas artificiales, el $22 \%$ en cunetas, cañadas y cursos de agua naturales y el $11 \%$ lo utiliza en aplicación al suelo. La información permitirá proponer estrategias de producción sustentable para los tambos de la región. Palabras claves: tambos; agua; efluentes; residuos; Santa Fe.
\end{abstract}

\section{SUMMARY}

Water use and effluent and resiues management in noorth east dairy farms Santa Fe province, Argentina.

Northeastern of Santa Fe, is one of the potential areas for dairy activity. Information was requested through a survey on environmental issues and its relation to management practices in dairy farms from Vera, General Obligado, Northern San Justo and San Javier departments. The main results indicated that $27 \%$ of dairy farm has some effluent management. Raw dairy effluent are derived to artificial ponds in $56 \%$ of farms, $22 \%$ to natural watercourses and $11 \%$ is used to apply to the soil, as fertilizer. Information will be used to propose strategies for dairy farm in the region.

Key Words: Dairy farm, Water, effluent, livestock waste, North East of Santa Fe Province.

1.- Facultad de Ciencias Agrarias, Universidad Nacional del Litoral. Kreder 2805. (3080) Esperanza, provincia de Santa Fe. Email: obadino@fca.unl.edu.ar

2.- Instituto Nacional de Tecnología Industrial (INTI) Lácteo. Rafaela, provincia de Santa Fe.

3.- Facultad de Ciencias Veterinarias. UBA.

aProyecto Financiado por CAI+D 2011. Código 5012011100127.

Manuscrito recibido el 3 de febrero de 2015 y aceptado para su publicación el 2 de junio de 2015. 